\title{
RESPONSE OF GROWTH, YIELD AND ITS COMPONENTS AND MICROENVIRONMENTAL FACTORS OF COTTON PLANT TO NITROGEN FERTILIZER LEVELS, PLANT DISTRIBUTION AND DENSITIES \\ Gebaly, Sanaa G. \\ Cotton Research Institute, Agricultural Research Center, Giza
}

\begin{abstract}
Two field experiments were conducted during summer seasons of 2006 and 2007. The aim of this investigation was to study the effect of relationship among nitrogen level and plant distribution with growth, yield and its components and micro environmental factors in cotton fields.

Twelve treatments which were the combination of three plant densities and distribution of cotton cv.80 i.e 45000, 60000 and 75000 plants /fed. were resulted from inter ridge widths $(80,40$ and $60 \mathrm{~cm})$ within ridge spacing $(20,15$ and $15 \mathrm{~cm})$ and (two, one and two plants/hill) respectively. And four nitrogen levels (55, 70, 85 and $100 \mathrm{~kg} \mathrm{~N} / \mathrm{fed}$.) were assigned in split-plot design with four replication. Environmental characters were determined at 70,100,130 and 160 days from sowing.

The data revealed that plant length and the number of leaves/plant were significantly increased by increasing nitrogen levels from 55 to $100 \mathrm{~kg} \mathrm{~N} / \mathrm{fed}$. The rate of increased was higher at the addition of $100 \mathrm{~kg} \mathrm{~N} / \mathrm{fed}$. as compared with other nitrogen rates. Increase nitrogen levels decreasing boll weight and cotton yield/fed. As the nitrogen rates increased, the light penetration was significantly decreased as the lower third of plant, the air canopy, leaf and soil temperature were tended to decrease. Also the relative humidity (R.H) in cotton canopy tended to increase by increasing nitrogen fertilizer rates. This was true at the different stages of growth (i.e. 70, 100, 150 and 160 days from sowing)during the two successive seasons of 2006 and 2007. By increasing the plant density from 45000 to 75000 plants per feddan., length plants were increased, but the number of leaves and fruiting branches/plant was decreased significantly. Boll weight and seed cotton yield/plant and feddan increased by decreasing plant density from 75 to 45 thousand plants/fed. in both seasons. As the plant density per unit area increased the light penetration was significantly decreased. The decrease was greater at the lower third as compared with that mid plant. also increasing plant density, the air canopy, leaf and soil temperature $\left({ }^{0} \mathrm{C}\right)$ were decreased at $70,100,130$ and 160 days after sowing in both seasons, the relative humidity tended to increase by increasing the plant density from 45000 to 75000 plants/fed.

All the interaction between plant density and distribution and nitrogen levels on growth, micro environmental factors in cotton field at different stage of growth i.e $70,100,130$ and 160 days after sowing and yield and its components in this investigation did not reach the $5 \%$ level of significance.
\end{abstract}

Keywords: Cotton, Nitrogen levels, Plant distribution, and densities, Microenvironmental factors.

\section{INTRODUCTION}

In recent years, there has been serious efforts directed at increasing cotton production in Egypt. Factors such as soil fertility and plant stand density are all known to effect yield levels. Interactions of there factors for each agro climatic zone are of primary importance for increasing productivity of cotton. 
Gebaly, Sanaa G.

El-Gahel et al (1990) stated that plant length, number of fruiting branches, seed cotton yield/fed. and plant yield, boll weight and number of bolls were increased as nitrogen levels increased in soil. While El-Shahawy et el (1994) reported that cotton traits, plant length, dry weight, length of internode/plant were insignificantly increased as nitrogen levels were increased from 45 to $85 \mathrm{~kg} / \mathrm{fed}$. Whereas, Makram et al (1995) stated that increasing soil temperature decreased number of days for completion of germination and increased germination percentage, plant growth was slightly affected by planting dates. Yield components and yield of seed cotton were increased in favor of early sowing. However, El-Shahawy et al (1997), reported that increasing plant density significantly increased final plant length, number of sympodial branches/plant, shedding percentage, earliness percentage, however, number of main stem internodes and number of unopened bolls/plant significantly increased by increasing plant density. In contrary, decreasing plant density led to a significant increase in number of monopodial branches/plant, boll setting percentage and boll weight.

Ismail et al (2000) showed that growing cotton plants at $30 \mathrm{~cm}$ between hills (low stands) increased seed cotton yield/plant.

But El-Gahel et al (1991) reported that seed cotton yield/fed. were not significantly affected by plant population (46.666 to 75000 and 140000 plants/fed.). On the other hand, increasing nitrogen levels from 60 to 120 $\mathrm{kgN} / \mathrm{fed}$. caused an increase in boll weight (El-Shahawy et al (1999).

On the contrary, Ismail et al (2000) reported that increasing nitrogen rates from 30 to $90 \mathrm{~kg} \mathrm{~N} / \mathrm{fed}$. had no significant effect on seed cotton yield/fed.

The aim of this study is to investigate how cotton plant c.v. Giza 80 growth, yield and its components and micro environmental factors respond to the increasing or decreasing of population and distribution $(45,60,75$ thousand plants/fed.) under the addition of different rates of nitrogen fertilizer (i.e 55, 70,85 and $100 \mathrm{~kg} \mathrm{~N} / \mathrm{fed}$.) and their interaction effects.

\section{MATERIALS AND METHODS}

Two field experiments were carried out at Sids experimental research station at Beni-Sweef Governorate 2006 and 2007 growing seasons. The aim of this work is to study the effect of plant distribution, density and nitrogen fertilization levels on both of growth, yield, yield components, fiber properties, micro - environmental factors in the cotton field. Seeds of cotton (Gossypium barbadense L) C.V. Giza 80 the recommended local cultivar for Beni-Sweef Governorate was planted on 24, and 13 March in 2006 and 2007 growing seasons, respectively. In the first growing season corn preceded berseem preceded by rice, whereas in the second season corn preceded berseem.

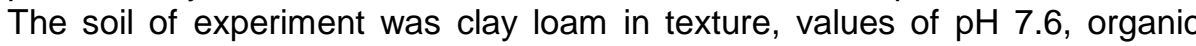
matter $2 \%$, total nitrogen $(1.29 \%)$, EC $\left(0.86\right.$ milimhos $/ \mathrm{cm}$ at $\left.25{ }^{\circ} \mathrm{c}\right)$ and $\mathrm{CaCo}_{3}$ $(1.81 \%)$. during the two seasons of experimentation, single calcium superphosphate $\left(15.5 \% \mathrm{P}_{2} \mathrm{O}_{5}\right)$ at the rate $200 \mathrm{~kg} / \mathrm{fed}$. and potassium sulfate $\left(48 \% \mathrm{~K}_{2} \mathrm{O}\right)$ at the rate of $50 \mathrm{~kg} / \mathrm{fed}$. were added before riding. Nitrogen fertilizer was applied as form $(46 \% \mathrm{~N})$. Nitrogen rates were applied in two 
equal parts before the first and second irrigation (30 and 45 days after sowing). Each experiment included twelve treatments which were the combinations of following:

\section{A- Nitrogen fertilization rates were:-}

$1-55 \mathrm{~kg} \mathrm{~N} / \mathrm{fed} .2-70 \mathrm{~kg} \mathrm{~N} / \mathrm{fed}$. $\quad 3-85 \mathrm{~kg} \mathrm{~N} / \mathrm{fed} . \quad 4-100 \mathrm{~kg} / \mathrm{fed}$.

B- Plant distribution and density were:-

1- 45000 plant/fed.: plants were adjusted as two plants per hill at a distance $20 \mathrm{~cm}$ between plants in rows $80 \mathrm{~cm}$ a part.

2- 60000 plant/fed.: plants were adjusted as one plant per hill at a distance 15 $\mathrm{cm}$ between plants in rows $40 \mathrm{~cm}$ a part.

3- 75000 plant/fed.: plants were adjusted as two plants per hill at a distance $15 \mathrm{~cm}$ between plants in rows $60 \mathrm{~cm}$ a part.

The experimental design used was split plot design in four replicates.

Plant distribution and density treatments occupied the main plots and treatments of nitrogen rates were allocated at random in the sub plots. The area of sub plot was $38.4 \mathrm{~m}^{2}$ consisting of 8 and 16 ridges of 6 meters length for the first and second plant density, while sub plot was $43.2 \mathrm{~m}^{2}$ consisting 12 ridges of $6 \mathrm{~m}$ length for the third plant density (75000 plant/fed.).

Normal agricultural practices for growing cotton were practiced properly.

A random sample of five guarded plants was chosen from each sub plot at $70,100,130$ and 160 days from sowing.

Plants were carried immediately to laboratory where the following were obtained:-

1- Plant length $\mathrm{cm}$

2- Number of leaves/plant

3-Number of fruiting branches/plant

4- Number of bolls/plant

The following micro climatic data was measured at 70, 100, 130 and 160 days after sowing:-

\section{1- Light penetration percentage:}

Light intensity was recorded at ground level, the mid plant and plant top, respectively by using Environmental Multi Probe equipment at 110 Clock a.m. The penetration percentage was calculated by rating the light intensity at the mid plant and at ground level to that at the plant top.

\section{2- Soil temperature:}

The soil temperature was measured by using normal thermometer which was put at a depth of $10 \mathrm{~cm}$ from ground surface at $11 \mathrm{O}$ Clock a.m. between plants for one minute.

3- Air temperature of the treatment $\left({ }^{\circ} \mathrm{C}\right)$ :

The air temperature was estimated by putting the apparatus (Environment Multi probe) for one minute between cotton plants at

110 Clock a.m.

4- The leaf temperature $\left({ }^{0} \mathrm{c}\right)$ :

This was measured by touching the resistance of the apparatus (Environment Multi probe) with the upper leaf surface at mid-day for one minute.

5- The relative humidity (\%):

The relative humidity was measured by putting the hygrometer equipment between cotton plants for two minutes at $11 \mathrm{O}^{\circ}$ Clock a.m. 
Gebaly, Sanaa G.

Cotton was harvested on September $23^{\text {th }}$ in the first season and on October $3^{\text {rd }}$ in the second season. The following data were recorded:-

1 - Average weight of boll ( $\mathrm{g}$ ).

2- Average number of mature bolls/plant.

3- No. of opening bolls \%.

4- Seed cotton yield (g/plant.).

5- Seed cotton yield (Kentar/fed.).

Kentar $=157.5 \mathrm{~kg}$ of seed cotton.

Fiber properties: micrometer value and pressely index.

The data obtained from each trial were subjected to the analysis of variance of split plot design as described by Snedecer and Cochran (1982). However, treatments means were compared using the least significant difference (L.S.D) test developed by Gomez and Gomez (1983) at the 5\% level.

\section{RESULTS AND DISCUSSION}

\section{A- Effect of nitrogen fertilization rates on:- 1- Growth:}

The results in Table (1) show that as the nitrogen levels increased from 55 to $100 \mathrm{~kg} \mathrm{~N} / \mathrm{fed}$., the plant length was increased.

This was true at the different stages of growth i.e 70,100,130 and 160 days after sowing in both seasons. The rate of increase of plant length was higher at the addition of $100 \mathrm{~kg} \mathrm{~N} / \mathrm{fed}$. as compared with other nitrogen rates.

It could be concluded that increasing nitrogen fertilization levels caused a significant increase in the elongation of cotton plants, with a high rate at the addition of $100 \mathrm{~kg} / \mathrm{fed}$. This result might be attributed to the effect of adding nitrogen on accelerating early vegetative growth and increasing number and /or length of internode. The increase in plant length probably resulted from the increase in the activity of meristematic tissues due to the increase in the rate of cell division and elongation. This was an attribute to the more assimilation of amino acids, nucleic acids. Peptides and proteins in relation to the availability of more nitrogen. The obtained results are in agreement with those obtained by Mc Farland et al 1999 and Perumal 1999.

Data concerning the number of leaves/plant at the different growth stages in both seasons are presented in Table (1). It was appeared that as the nitrogen rates increased the number of leaves/plant were significantly increased. This was true at the different stages of growth in both seasons. The rate of increase of number of leaves per plant was higher at the addition of $100 \mathrm{~kg} \mathrm{~N} / \mathrm{fed}$. as compared with other nitrogen levels. Confirming results were obtained by (Heitholt et al 1998 and Perumal 1999).

The results in Table (1) show no relationship between number of fruiting branches/plant and bolls/plant and amounts of nitrogen added to the plants at different stages of growth i.e 70,100,130 and 160 days after sowing in both seasons. Similar results were obtained by Moore (1999) and Perumal (1999). 


\section{2- Micro- environmental factors in cotton fields:}

Data presented in Table (2) show that the effect of nitrogen fertilization levels added to cotton plants on the percentage of light intensity penetration found along cotton plants from the top to the lower third of plant, air temperature $\left({ }^{0} \mathrm{C}\right)$, leaf temperature $\left({ }^{0} \mathrm{C}\right)$, soil temperature $\left({ }^{0} \mathrm{C}\right)$ and relative humidity at $70,100,130$ and 160 days from sowing. as the nitrogen fertilization rates increased from 55 to $100 \mathrm{~kg} \mathrm{~N} / \mathrm{fed}$. The light penetration was decreased significantly at lower third more than the mid plant. This true at different stages of growth in both seasons.

This means that adding nitrogen fertilization tends to catch more light energy at the upper layer of the canopy cover than at the lower parts. This may be due to the increase in the leaves formation and leaves area as well as leaf area index according to the increase in the nitrogen rates. The resultant was producing more photosynthetic apparatus and consequently more interaction of the incident light. According, less light intensity was expected to penetration down. Makram et al 1994 and El-Shahawy 1997, they pointed out that light intensity at the mid and bottom of cotton plants was decreased by increasing nitrogen fertilization rates.

Table (1): Effect of nitrogen fertilization levels on plant canopy of cotton at different stages during 2006 and 2007 seasons.

\begin{tabular}{|c|c|c|c|c|c|c|c|c|}
\hline \multirow{3}{*}{\begin{tabular}{|l|} 
\\
Nitrogen \\
rates \\
(kg/fed.)
\end{tabular}} & \multicolumn{8}{|c|}{ Characters } \\
\hline & \multicolumn{4}{|c|}{2006} & \multicolumn{4}{|c|}{2007} \\
\hline & $\begin{array}{l}\text { Plant } \\
\text { length } \\
\text { "cm" }\end{array}$ & $\begin{array}{c}\text { Number } \\
\text { of } \\
\text { leaves/ } \\
\text { plant }\end{array}$ & $\begin{array}{c}\text { Number of } \\
\text { fruiting } \\
\text { branches/ } \\
\text { plant }\end{array}$ & $\begin{array}{c}\text { Number } \\
\text { of bolls/ } \\
\text { plant }\end{array}$ & $\begin{array}{c}\text { Plant } \\
\text { length } \\
\text { "cm" }\end{array}$ & $\begin{array}{c}\text { Number } \\
\text { of leaves/ } \\
\text { plant }\end{array}$ & $\begin{array}{c}\text { Number of } \\
\text { fruiting } \\
\text { branches/ } \\
\text { plant }\end{array}$ & $\begin{array}{c}\text { Number } \\
\text { of bolls/ } \\
\text { plant }\end{array}$ \\
\hline \multicolumn{9}{|c|}{ At 70 days after sowing } \\
\hline 55 & 30.4 & 15.1 & 4.2 & 0.0 & 34.1 & 15.6 & 5.1 & 0.0 \\
\hline 70 & 32.1 & 16.2 & 4.9 & 0.0 & 36.1 & 16.5 & 4.7 & 0.0 \\
\hline 85 & 32.8 & 16.9 & 4.5 & 0.0 & 37.8 & 17.6 & 4.5 & 0.0 \\
\hline 100 & 35.7 & 17.0 & 4.4 & 0.0 & 39.0 & 18.2 & 3.9 & 0.0 \\
\hline L.S.D at $5 \%$ & 1.76 & 0.58 & N. S & - & 0.84 & 1.04 & N. S & - \\
\hline \multicolumn{9}{|c|}{ At $\mathbf{1 0 0}$ days after sowing } \\
\hline 55 & 61.8 & 19.3 & 8.4 & 0.9 & 75.5 & 19.1 & 9.6 & 1.5 \\
\hline 70 & 65.4 & 20.0 & 8.1 & 1.2 & 78.4 & 19.9 & 9.2 & 1.7 \\
\hline 85 & 65.9 & 20.8 & 8.9 & 1.2 & 80.8 & 21.0 & 8.8 & 1.8 \\
\hline 100 & 67.1 & 21.5 & 8.8 & 1.3 & 83.8 & 21.8 & 8.2 & 1.9 \\
\hline L.S.D at $5 \%$ & N.S & 1.18 & N. S & N. S & 1.57 & 0.78 & N. S & N. S \\
\hline \multicolumn{9}{|c|}{ At 130 days after sowing } \\
\hline 55 & 92.4 & 26.4 & 14.9 & 7.9 & 92.6 & 29.0 & 14.4 & 8.5 \\
\hline 70 & 100.3 & 28.6 & 14.5 & 8.1 & 100.1 & 31.7 & 14.1 & 9.1 \\
\hline 85 & 105.0 & 29.5 & 14.3 & 8.6 & 102.9 & 33.1 & 13.8 & 9.7 \\
\hline 100 & 106.4 & 30.6 & 13.3 & 8.9 & 104.4 & 34.9 & 13.4 & 10.3 \\
\hline L.S.D at $5 \%$ & 2.09 & 1.82 & N.S & N.S & 2.79 & 1.24 & N.S & N.S \\
\hline \multicolumn{9}{|c|}{ At 160 days after sowing } \\
\hline 55 & 100.5 & 32.2 & 15.4 & 13.3 & 101.6 & 33.5 & 15.8 & 12.7 \\
\hline 70 & 105.8 & 33.1 & 15.2 & 14.4 & 106.3 & 34.5 & 15.7 & 13.4 \\
\hline 85 & 109.6 & 33.8 & 14.7 & 14.7 & 108.3 & 35.3 & 14.8 & 13.7 \\
\hline 100 & 111.7 & 36.8 & 14.3 & 15.0 & 111.0 & 37.3 & 14.2 & 14.0 \\
\hline L.S.D at $5 \%$ & 3.12 & 1.90 & N. S & N.S & 3.19 & 1.15 & N.S & N. S \\
\hline
\end{tabular}


Gebaly, Sanaa G.

As the nitrogen levels applied to the cotton plants increased, the air canopy, leaf and soil temperature were shown to decrease (Table 2).

This was true at the different stages of growth studied i.e 70, 100, 130 and 160 days after sowing in both seasons. These results might be attributed to the significant positive effect of nitrogen on enhancing the vegetative growth of cotton plants and accelerates the rate of leaf growth. Also increase leaves area and leaf area index and canopy cover of the plant was great enough to intercept the mostly incidence light at upper layer. At the age of 160 days after sowing in both seasons, the soil temperature start to increase due to the decrease in the canopy cover, which will result in an increase in the penetrated light energy to the soil surface, more increase in soil temperature could be expected.

Table (2): Effect of nitrogen fertilization levels on micro environment factors in the field of cotton plants at different stages during 2006 and 2007 seasons.

\begin{tabular}{|c|c|c|c|c|c|c|c|c|c|c|c|c|}
\hline \multirow{4}{*}{\begin{tabular}{|l} 
\\
\\
Nitrogen \\
rates \\
(kg/fed.)
\end{tabular}} & \multicolumn{12}{|c|}{ Characters } \\
\hline & \multicolumn{6}{|c|}{2006} & \multicolumn{6}{|c|}{2007} \\
\hline & \multicolumn{2}{|c|}{$\begin{array}{c}\% \text { Light } \\
\text { intensity }\end{array}$} & \multicolumn{3}{|c|}{$\begin{array}{c}\text { Temperature } \\
\left({ }^{\circ} \mathrm{C}\right) \text { of }\end{array}$} & \multirow{2}{*}{ 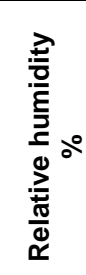 } & \multicolumn{2}{|c|}{$\begin{array}{l}\% \text { Light } \\
\text { intensity }\end{array}$} & \multicolumn{3}{|c|}{$\begin{array}{c}\text { Temperature } \\
\left({ }^{0} \mathrm{C}\right) \text { of }\end{array}$} & \multirow{2}{*}{ 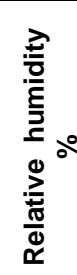 } \\
\hline & 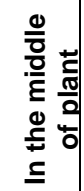 & 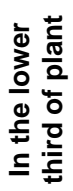 & $\begin{array}{l}\text { 응 } \\
\frac{1}{\mathbb{D}} \\
\text { 흥 }\end{array}$ & leaf & soil & & 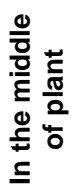 & 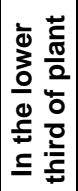 & $\begin{array}{l}\text { 응 } \\
\frac{0}{\mathbb{8}} \\
\frac{1}{\bar{J}}\end{array}$ & leaf & soil & \\
\hline \multicolumn{13}{|c|}{ At $\mathbf{7 0}$ days after sowing } \\
\hline 55 & 67.3 & 54.2 & 36.5 & 35.5 & 26.6 & 63.5 & 57.2 & 42.1 & 37.5 & 36.7 & 33.9 & 63.3 \\
\hline 70 & 66.7 & 52.1 & 36.3 & 35.1 & 26.2 & 63.9 & 54.3 & 40.4 & 37.3 & 36.4 & 33.5 & 63.7 \\
\hline 85 & 65.2 & 50.4 & 36.0 & 35.0 & 25.9 & 64.5 & 51.7 & 39.1 & 37.1 & 36.2 & 33.4 & 63.9 \\
\hline 100 & 63.8 & 47.5 & 35.8 & 34.6 & 25.7 & 65.0 & 50.6 & 36.5 & 36.7 & 36.2 & 32.8 & 64.4 \\
\hline L.S.D at $5 \%$ & 0.51 & 0.99 & 0.31 & NS & 0.26 & NS & 1.55 & 1.69 & NS & 0.29 & 0.30 & 0.79 \\
\hline \multicolumn{13}{|c|}{ At 100 days after sowing } \\
\hline 55 & 60.4 & 45.7 & 36.6 & 36.1 & 27.1 & 77.4 & 50.5 & 36.8 & 36.2 & 36.1 & 32.6 & 75.0 \\
\hline 70 & 59.0 & 44.2 & 36.2 & 35.9 & 26.9 & 78.0 & 47.6 & 34.2 & 36.1 & 35.9 & 32.4 & 75.5 \\
\hline 85 & 56.6 & 42.0 & 63.0 & 35.8 & 26.1 & 78.9 & 45.7 & 32.6 & 35.9 & 35.8 & 32.2 & 75.7 \\
\hline 100 & 54.9 & 40.1 & 63.0 & 35.6 & 26.0 & 79.3 & 43.0 & 31.2 & 35.8 & 35.5 & 32.1 & 75.8 \\
\hline L.S.D at $5 \%$ & 1.42 & 0.96 & NS & NS & 0.60 & 0.63 & 1.28 & 1.34 & NS & 0.25 & NS & 0.52 \\
\hline \multicolumn{13}{|c|}{ At 130 days after sowing } \\
\hline 55 & 55.3 & 40.1 & 35.9 & 35.6 & 27.2 & 77.1 & 43.9 & 30.0 & 33.9 & 33.0 & 31.4 & 77.4 \\
\hline 70 & 54.4 & 38.7 & 35.7 & 35.4 & 26.8 & 77.5 & 42.0 & 28.3 & 33.5 & 32.5 & 30.8 & 78.3 \\
\hline 85 & 52.2 & 36.9 & 35.5 & 35.4 & 26.7 & 77.7 & 40.3 & 27.1 & 33.4 & 32.1 & 30.4 & 78.7 \\
\hline 100 & 49.1 & 34.4 & 35.4 & 35.4 & 26.4 & 78.0 & 39.3 & 25.8 & 32.8 & 31.9 & 30.4 & 78.9 \\
\hline L.S.D at $5 \%$ & 1.07 & 0.51 & NS & NS & NS & NS & 1.25 & 1.05 & NS & 0.30 & 0.47 & 0.69 \\
\hline \multicolumn{13}{|c|}{ At 160 days after sowing } \\
\hline 55 & 47.2 & 27.2 & 36.9 & 36.7 & 28.8 & 68.0 & 27.2 & 23.1 & 36.9 & 36.3 & 28.2 & 71.9 \\
\hline 70 & 46.9 & 26.9 & 36.7 & 36.4 & 28.7 & 68.1 & 27.1 & 23.0 & 36.9 & 36.2 & 28.0 & 72.4 \\
\hline 85 & 44.3 & 25.9 & 36.4 & 36.2 & 28.1 & 68.6 & 26.8 & 22.9 & 36.7 & 36.0 & 26.9 & 72.9 \\
\hline 100 & 42.8 & 24.9 & 36.2 & 35.8 & 28.0 & 69.1 & 26.8 & 22.7 & 36.4 & 35.9 & 26.8 & 73.3 \\
\hline L.S.D at $5 \%$ & 0.51 & 1.71 & NS & 0.38 & NS & 0.68 & 0.32 & NS & NS & 0.26 & NS & 0.47 \\
\hline
\end{tabular}

The obtained results indicate that the relative humidity (R.H) in cotton canopy tended to increase by increasing nitrogen fertilizer from 55 to $100 \mathrm{~kg}$ 
$\mathrm{N} / \mathrm{fed}$. This was true at the different stages of growth measured in both seasons. This may be to the increase of evapo tran piration from plant canopy and/or evaporation from soil surface.

\section{3- Cotton yield and its components:}

Data presented in Table (3) show that the increase of nitrogen fertilizer levels increased number of bolls/plant. Nitrogen fertilizer caused an increase in the amount of metabolites synthesized by the plant. The results indicated that increasing level of nitrogen extended the plant length and could be considered as an outward expression of the meristematic activity of the plant. Therefore, it is suggested that nitrogen favor the meristematic activity and extension of cells in cotton plants. Mc Connell et al (1998) and Moore (1999) concluded similar results Increasing nitrogen fertilizer levels from 55 to $100 \mathrm{~kg} \mathrm{~N} / \mathrm{fed}$., decreased boll weight (g), seed cotton yield/plant and feddan. These results can be explained on the fact that moderate $\mathrm{N}$. level applied for plants leads to keep balance proportion between the vegetative and fruiting growth. Adding nitrogen fertilizer from 55 to $100 \mathrm{~kg} \mathrm{~N} / \mathrm{fed}$. decreased seed cotton yield/fed. in both seasons. This may be due to the increase number of leaves/plant and the leaf area, which consequently increased the amount of light energy, intercepted by leaves partitioned to fruiting organs. Such results were confirmed by Bondada et al (1999) and Moore (1999).

Table (3): Effect of nitrogen fertilizer levels on yield and its components of cotton plants during 2006 and 2007 seasons.

\begin{tabular}{|c|c|c|c|c|c|c|c|c|}
\hline & \multicolumn{9}{|c|}{$\mathbf{2 0 0 6}$} & \multicolumn{3}{c|}{ Characters } \\
\hline $\begin{array}{c}\text { Nitrogen } \\
\text { rates } \\
\mathbf{( k g / f e d )}\end{array}$ & $\begin{array}{c}\text { Number of } \\
\text { bolls/ } \\
\text { plant }\end{array}$ & $\begin{array}{c}\text { Boll } \\
\text { Weight } \\
\text { (g) }\end{array}$ & $\begin{array}{c}\text { Seed } \\
\text { yield } \\
\text { per plant } \\
\text { (g) }\end{array}$ & $\begin{array}{c}\text { Seed yield } \\
\text { Kentar/ } \\
\text { fed. }\end{array}$ & $\begin{array}{c}\text { Number } \\
\text { of boll } \\
\text { per } \\
\text { plant }\end{array}$ & $\begin{array}{c}\text { Boll } \\
\text { weight } \\
\text { (g) }\end{array}$ & $\begin{array}{c}\text { Seed } \\
\text { yield per } \\
\text { plant } \\
\text { (g) }\end{array}$ & $\begin{array}{c}\text { Seed yield } \\
\text { Kentar/ } \\
\text { fed. }\end{array}$ \\
\hline 55 & 24.8 & 2.49 & 26.70 & 9.59 & 21.2 & 2.60 & 20.03 & 7.22 \\
70 & 25.4 & 2.46 & 25.21 & 9.05 & 21.4 & 2.47 & 18.33 & 6.61 \\
85 & 26.6 & 2.27 & 21.83 & 7.84 & 21.9 & 2.36 & 16.63 & 6.4 \\
100 & 26.9 & 2.25 & 20.43 & 6.42 & 22.5 & 2.11 & 15.09 & 5.44 \\
L.S.D at 5\% & 0.18 & 0.15 & 1.90 & 0.52 & 0.14 & 0.15 & 1.34 & 0.43 \\
\hline
\end{tabular}

\section{B- Effect of plant density and distribution on:-}

1- Growth:

The results in Table (4) show that higher plants were obtained when the plant density increased from 45 to 75 thousand plants/fed. The more rate of increase in the plant elongation was obtained at the plant density of 75000 plant/fed. This was true at the different stages of growth in both seasons. It could be concluded that increasing cotton plant density till 75000 plants/fed. was shown to encouraged the plants to elongate more. as the occupied area by every plant decreased in relation to the increase in the plant density, the plant as a result will start to elongate more to interception for light energy. Accordingly, the more consumption of nutrients from soil will occur and consequently more elongation would happened due to the availability of nutrient demands. On the other hand, shadowing for plants under the increase in plant density, more growth substances responsible for cell 
division and elongation such as auxins were expected to form and consequently more plant elongation will obtained. These findings are in agreement with those recorded by Makram et al (1994) and El-Shahawy et al (1997).

Results in Table (4) indicate a significant decrease in the plant leaves number of cotton plants as the plant density increased from 45 to 75 thousand plants/fed. This was true under the different stages of growth studied in both seasons. It could be concluded that increasing plant distance as well as decreasing plant density per unit area were resulted in an increase in the leaf extension and total area. Widening the distances between plants permit to intercept more light energy of incident light as well as more light can penetrate to lower parts of the plant which could help this to be more efficient and active for a long period. The resultant will be more production of photosynthesis which can be used in a leaf extension.

Table (4): Effect of plant distribution and density on growth of cotton plants at different stages during 2006 and 2007 seasons.

\begin{tabular}{|c|c|c|c|c|c|c|c|c|}
\hline \multirow{3}{*}{\begin{tabular}{|c|} 
\\
Plant \\
distributi \\
on and \\
density \\
(plant/ \\
fed.)
\end{tabular}} & \multicolumn{8}{|c|}{ Characters } \\
\hline & \multicolumn{4}{|c|}{2006} & \multicolumn{4}{|c|}{2007} \\
\hline & $\begin{array}{l}\text { Plant } \\
\text { length } \\
\text { "cm" }\end{array}$ & $\begin{array}{c}\text { Number } \\
\text { of } \\
\text { leaves/ } \\
\text { plant }\end{array}$ & $\begin{array}{c}\text { Number of } \\
\text { fruiting } \\
\text { branches } / \\
\text { plant }\end{array}$ & $\begin{array}{c}\text { Number } \\
\text { of bolls/ } \\
\text { plant }\end{array}$ & $\begin{array}{l}\text { Plant } \\
\text { length } \\
\text { "cm" }\end{array}$ & $\begin{array}{c}\text { Number } \\
\text { of leaves/ } \\
\text { plant }\end{array}$ & $\begin{array}{c}\text { Number of } \\
\text { fruiting } \\
\text { branches } \\
\text { /plant }\end{array}$ & $\begin{array}{c}\text { Number } \\
\text { of bolls/ } \\
\text { plant }\end{array}$ \\
\hline \multicolumn{9}{|c|}{ At 70 days after sowing } \\
\hline 45000 & 31.1 & 18.2 & 5.0 & 0.0 & 33.6 & 18.2 & 5.0 & 0.0 \\
\hline 60000 & 32.5 & 17.0 & 4.4 & 0.0 & 37.7 & 16.8 & 4.5 & 0.0 \\
\hline 75000 & 37.4 & 14.9 & 4.4 & 0.0 & 38.7 & 15.9 & 4.2 & 0.0 \\
\hline L.S.D at $5 \%$ & 1.76 & 1.61 & 5.24 & - & 0.73 & 0.90 & 0.25 & 0.0 \\
\hline \multicolumn{9}{|c|}{ At 100 days after sowing } \\
\hline 45000 & 55.4 & 21.6 & 9.6 & 1.6 & 74.1 & 21.6 & 10.3 & 2.0 \\
\hline 60000 & 66.5 & 20.3 & 8.6 & 1.3 & 82.3 & 20.8 & 8.6 & 1.7 \\
\hline 75000 & 66.8 & 20.2 & 8.4 & 0.8 & 82.5 & 19.0 & 10.7 & 1.4 \\
\hline L.S.D at $5 \%$ & 1.55 & 0.85 & 0.24 & 0.27 & 1.36 & 0.76 & 0.42 & 0.25 \\
\hline \multicolumn{9}{|c|}{ At 130 days after sowing } \\
\hline 45000 & 101.7 & 30.4 & 14.6 & 9.8 & 98.0 & 32.4 & 14.1 & 10.4 \\
\hline 60000 & 105.0 & 30.1 & 14.0 & 8.0 & 99.2 & 32.1 & 14.0 & 9.7 \\
\hline 75000 & 105.0 & 28.0 & 13.8 & 7.7 & 102.9 & 32.0 & 13.7 & 8.1 \\
\hline L.S.D at $5 \%$ & 2.09 & 1.89 & 0.47 & 0.73 & 2.41 & 0.30 & 0.41 & 0.65 \\
\hline \multicolumn{9}{|c|}{ At 160 days after sowing } \\
\hline 45000 & 112.0 & 42.3 & 15.4 & 22.9 & 108.1 & 41.9 & 15.8 & 21.5 \\
\hline 60000 & 112.9 & 33.9 & 15.1 & 21.9 & 109.5 & 38.7 & 15.6 & 20.6 \\
\hline 75000 & 115.5 & 33.0 & 14.8 & 21.1 & 111.2 & 35.6 & 15.5 & 16.5 \\
\hline L.S.D at $5 \%$ & 1.22 & 1.27 & 0.29 & 1.20 & 2.85 & 1.24 & 0.85 & 1.04 \\
\hline
\end{tabular}

The number of fruiting branches/plant decreased significantly by increasing plant density from 45 to 75 thousand plants/fed. at the different stages of growth in both seasons. The decrease in number of fruiting branches/plant accompanied with the increase in plant density, may be due to more competition between plants for nutrients, moisture and light at such population. The increase in IAA concentration along cotton stem in dense planting might inhibit the development of buds to fruiting branches. These 
results are in general agree with those obtained by Makram et al (1994) and Mc Farland et al (1999).

Thin planting increases number of bolls/plant at different stages of growth in both seasons mainly due to increase in number of fruiting branches. Wide spacing may also furnished favorable environmental conditions i.e climatic and edifice factors to cotton plants to grow and to produce productive organs than dense planting. Similar results were obtained by El-Shahawy et al (1997)

\section{2- Micro- environmental factors in cotton fields:}

Data in table (5) show that as the plant density per unit area increased from 45 to 75 thousand plants/fed.,the light penetration was decreased significantly. the decrease was more greater at the lower third as compared with at mid plant. this was true at the different stages of growth after sowing in both seasons. It could be concluded that decreasing plant densities from 75 to 45 thousand plants/fed. tend to increase the degree of penetration of light through the cotton plant canopy. This may be attributed mainly to the less leaf canopy and less geometrical distribution of it in order to permit for the large degree of penetration. Increase the total leaves area per plant as well as increase in leaf area index which could intercept most of the incident light and prevent its penetration down as a resultant for increase plant densities. Similar results were obtained by Yassen et al (1990). who found that plant density and distance between plants are affecting highly on leaf area which play an important role in efficiency of caught more light energy and photosynthesis process.

Results in Table (5) show that as the plant density per unit area increased, the air canopy, leaf and soil temperature $\left({ }^{0} \mathrm{C}\right)$ were decreased. This was true at the different stages of growth measured in both seasons. This may be due to the increase in the vegetative cover, little amount of light energy to the soil surface, which in turn will result in decreasing of water evaporation from soil and the soil moisture content. Similar results were reported by Makram et al (1995).

The obtained results indicate that the relative humidity (R.H) in cotton canopy tended to increase by increasing plant density from 45 to 75 thousand plants/fed. at 70,100, 130 and 160 days after sowing in both seasons. This may be due to the increase in evapotranspiration from plant canopy and/or evaporation soil surface.

\section{3- Cotton yield and its components:}

Number of bolls/plant decreased significantly by increasing plant density from 45 to 75 thousand plants/fed. in both seasons (Table 6). This may be due to more competition between plants for nutrients, moisture and light at such population. The increase in IAA concentration along cotton stem in dense planting, might inhibit the development of buds to fruiting branches.

Boll weight $(\mathrm{g})$ was increased by decreasing plant density from 75 to 45 thousand plants/fed. in both seasons (Table 6). This may be due to the low competition between plants, wide spacing may also famished favorable environmental conditions i.e., climatic and edifice factors to cotton plants to grow and produce productive organs than dense planting. the lowest weight 
Gebaly, Sanaa G.

of seed cotton yield per plant was obtained from the higher plant population i.e. 75000 plants/fed.

Table (5): Effect of plant distribution and density on micro environment factors in the field of cotton plants at different stages during 2006 and 2007 seasons.

\begin{tabular}{|c|c|c|c|c|c|c|c|c|c|c|c|c|}
\hline \multirow{4}{*}{ 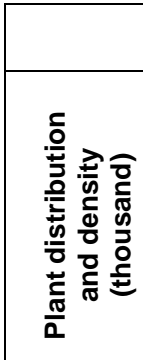 } & \multicolumn{12}{|c|}{ Characters } \\
\hline & \multicolumn{6}{|c|}{2006} & \multicolumn{6}{|c|}{2007} \\
\hline & \multicolumn{2}{|c|}{$\begin{array}{l}\text { \% Light } \\
\text { intensity }\end{array}$} & \multicolumn{3}{|c|}{$\begin{array}{c}\text { Temperature } \\
\left({ }^{0} \mathrm{c}\right) \text { of }\end{array}$} & \multirow{2}{*}{ 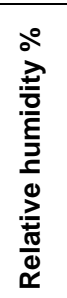 } & \multicolumn{2}{|c|}{$\begin{array}{l}\text { \% Light } \\
\text { intensity }\end{array}$} & \multicolumn{3}{|c|}{ Temperature $\left({ }^{0} \mathrm{c}\right)$ of } & \multirow{2}{*}{ 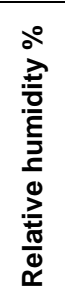 } \\
\hline & 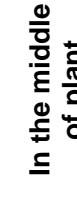 & 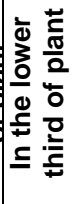 & 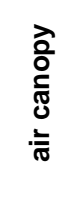 & leaf & Soil & & 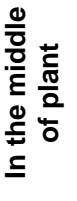 & 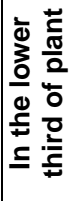 & $\begin{array}{l}\text { 응 } \\
\frac{0}{\mathbb{0}} \\
\text { 응 }\end{array}$ & leaf & soil & \\
\hline \multicolumn{13}{|c|}{ At 70 days after sowing } \\
\hline 45 & 66.6 & 53.5 & 36.4 & 35.6 & 26.2 & 62.5 & 60.0 & 44.5 & 38.3 & 37.4 & 35.0 & 60.8 \\
\hline 60 & 66.2 & 49.8 & 36.1 & 35.1 & 26.1 & 64.5 & 52.6 & 39.4 & 37.9 & 37.0 & 33.0 & 63.8 \\
\hline 75 & 62.9 & 46.7 & 34.9 & 34.0 & 25.5 & 66.4 & 47.9 & 34.7 & 35.2 & 34.6 & 32.3 & 67.0 \\
\hline L.S.D at $5 \%$ & 0.51 & 0.99 & 0.31 & 0.53 & 0.26 & 0.83 & 1.3 .5 & 1.47 & 0.70 & 0.25 & 0.26 & 0.68 \\
\hline \multicolumn{13}{|c|}{ At 100 days after sowing } \\
\hline 45 & 59.4 & 41.6 & 36.2 & 36.0 & 27.0 & 77.3 & 48.5 & 34.4 & 36.4 & 36.4 & 32.8 & 72.5 \\
\hline 60 & 57.6 & 44.1 & 36.1 & 35.9 & 26.2 & 79.1 & 46.3 & 33.8 & 36.2 & 36.0 & 32.3 & 74.9 \\
\hline 75 & 53.5 & 37.5 & 35.4 & 35.4 & 25.7 & 79.7 & 45.3 & 27.9 & 35.5 & 35.2 & 31.8 & 79.1 \\
\hline L.S.D at $5 \%$ & 0.42 & 0.96 & 0.37 & 0.32 & 0.60 & 0.65 & 1.11 & 1.16 & NS & 0.22 & 0.40 & 0.45 \\
\hline \multicolumn{13}{|c|}{ At 130 days after sowing } \\
\hline 45 & 55.6 & 39.2 & 36.0 & 35.9 & 27.3 & 77.0 & 42.4 & 29.7 & 35.0 & 33.8 & 31.9 & 76.4 \\
\hline 60 & 52.8 & 36.7 & 35.8 & 35.4 & 26.5 & 77.0 & 41.5 & 26.9 & 33.0 & 31.9 & 30.2 & 79.1 \\
\hline 75 & 47.3 & 34.2 & 34.8 & 34.8 & 26.3 & 77.4 & 37.6 & 26.8 & 32.3 & 31.4 & 30.2 & 79.5 \\
\hline L.S.D at $5 \%$ & 1.07 & 0.51 & 0.46 & 0.40 & 0.67 & 0.81 & 1.08 & 0.91 & 1.11 & 0.26 & 0.41 & 0.59 \\
\hline \multicolumn{13}{|c|}{ At 160 days after sowing } \\
\hline 45 & 45.9 & 26.9 & 37.4 & 37.0 & 31.7 & 67.5 & 27.3 & 23.1 & 37.1 & 36.4 & 26.4 & 70.5 \\
\hline 60 & 45.5 & 26.3 & 37.3 & 36.7 & 30.7 & 68.4 & 26.9 & 22.9 & 36.9 & 36.3 & 26.0 & 73.6 \\
\hline 75 & 43.1 & 24.5 & 34.4 & 34.1 & 30.0 & 70.5 & 26.8 & 22.8 & 36.3 & 35.7 & 25.6 & 73. 7 \\
\hline L.S.D at $5 \%$ & 0.51 & 1.74 & 0.32 & 0.38 & 0.68 & 0.68 & 0.28 & NS & NS & 0.22 & 0.39 & 0.41 \\
\hline
\end{tabular}

This may be due to the decrease in number fruiting branches/plant, number of bolls/plant and bolls weight in dense planting. Also the greater competition between plants for light, water and minerals may owe much for such finding. Under such condition small amounts of photosynthesis were partitions to the developing fruiting organs.

Results showed that seed cotton yield/fed., significantly decreased by increasing plant density (Table 6). this was true in both seasons of investigation. Higher seed cotton yield/fed., was obtained from 45000 plants/fed. It could be concluded that, decreasing plant density resulted in an increase in the bolls production of the plant. This may be due to attributed to the great variations between plants for the environmental sources especially light. these in true resulted in an increase in more rate of photosynthesis, dry matter production, great number of leaves with more extension more number fruiting branches/plant, more bolls/plant, more number open bolls/plant and 
more seeds/boll. All these results finally to produce more seed cotton yield/fed. Similar results were obtained by Presely et al (1999).

C- Effect of interaction:-

All the interaction between plant distribution and density and nitrogen levels on growth, micro environmental factors in cotton fields at the different stages i.e. $70,100,130$ and 160 days after sowing and yield and its components did not reach the $5 \%$ level of significances and were excluded, the in significant effect of plant distribution and density and nitrogen levels show that each of these two factors act independently on these characters.

Table (6): Effect of plant distribution and density on yield and its components of cotton plants during 2006 and 2007 seasons.

\begin{tabular}{|c|c|c|c|c|c|c|c|c|}
\hline & & & & Cha & racters & & & \\
\hline & & & 006 & & & & & \\
\hline $\begin{array}{c}\text { distribution } \\
\text { and } \\
\text { density } \\
\text { Plants/fed. } \\
\text { (thousand) }\end{array}$ & $\begin{array}{c}\text { Number } \\
\text { of bolls/ } \\
\text { plant }\end{array}$ & $\begin{array}{c}\text { Boll } \\
\text { Weight } \\
\text { (g) }\end{array}$ & $\begin{array}{l}\text { Seed } \\
\text { yield per } \\
\text { plant } \\
\text { (g) }\end{array}$ & $\begin{array}{c}\text { Seed } \\
\text { yield } \\
\text { Kentar/ } \\
\text { fed. }\end{array}$ & $\begin{array}{c}\text { Number } \\
\text { of boll } \\
\text { per } \\
\text { plant }\end{array}$ & $\begin{array}{c}\text { Boll } \\
\text { weight } \\
\text { (g) }\end{array}$ & $\begin{array}{l}\text { Seed } \\
\text { yield } \\
\text { Per } \\
\text { plant } \\
(\mathrm{g}) \\
\end{array}$ & $\begin{array}{c}\text { Seed } \\
\text { yield } \\
\text { Kentar/ } \\
\text { fed. }\end{array}$ \\
\hline 45000 & 28.4 & 2.75 & 37.75 & 9.96 & 24.7 & 2.65 & 23.90 & 6.83 \\
\hline 60000 & 25.9 & 2.30 & 22.16 & 8.47 & 21.8 & 2.30 & 16.43 & 6.28 \\
\hline 75000 & 22.6 & 2.16 & 16.87 & 8.04 & 18.7 & 2.28 & 12.29 & 5.87 \\
\hline L.S.D at $5 \%$ & 2.11 & 0.15 & 1.90 & 0.52 & 1.28 & 0.13 & 1.34 & 0.38 \\
\hline
\end{tabular}

Table (7): Effect of plant distribution and density on fiber quality and some chemical constituents of cotton plants during 2006 and 2007 seasons.

\begin{tabular}{|c|c|c|c|c|c|c|c|c|}
\hline & & 2006 & & & & 2007 & & \\
\hline Plant & & & $\mathrm{Se}$ & eds & & & & ds \\
\hline $\begin{array}{c}\text { and } \\
\text { density } \\
\text { Plants/fed. } \\
\text { (thousand) }\end{array}$ & $\begin{array}{c}\text { Micromaire } \\
\text { reading }\end{array}$ & $\begin{array}{c}\text { Pressley } \\
\text { Index }\end{array}$ & $\begin{array}{l}\text { Oil } \\
\%\end{array}$ & $\begin{array}{c}\text { Protein } \\
\%\end{array}$ & $\begin{array}{c}\text { Micromaire } \\
\text { Reading }\end{array}$ & $\begin{array}{c}\text { Pressley } \\
\text { Index }\end{array}$ & Oil \% & $\begin{array}{c}\text { Protein } \\
\%\end{array}$ \\
\hline 45000 & 4.59 & 9.70 & 18.60 & 21.70 & 4.72 & 9.55 & 18.50 & 21.56 \\
\hline 60000 & 4.70 & 10.00 & 19.60 & 21.80 & 4.80 & 9.75 & 19.70 & 21.60 \\
\hline 75000 & 4.50 & 9.60 & 18.68 & 21.88 & 4.60 & 9.65 & 18.79 & 21.77 \\
\hline L.S.D at $5 \%$ & 0.15 & N.S & 0.21 & 0.09 & 0.12 & NS & 0.20 & 0.05 \\
\hline
\end{tabular}

\section{REFERENCES}

Bondada, B.R; D.M Oosterhuis and N.P Tugwell (1999). Cotton growth and yield as influenced by different timing of late season foliar nitrogen fertilization. Nutrient cycle in Agro-ecosystems 54 (1): 1-18

El-Gahel, S.M (1991). Effect of some planting patterns on growth and yield of cotton. J. Agric. Res., Tanta Univ., Egypt 17 (3) : 375-383.

El-Gahel, S.M; M.M.El Razaz and H.M.Abou Zeid (1990). Effect of plant population and $\mathrm{N}$ and $\mathrm{P}$ fertilization on Giza 87 cotton variety. Agric. Res. Rev., pp 501. 
Gebaly, Sanaa G.

El-Shahawy, M.I.; and R.R. ABD El-Malik (1999). Response of Giza 87 cotton cultivar (Gossypium barbadense L.) to irrigation intervals and nitrogen fertilization levels Egypt. J. Agric. Res. 72 (2): 841-855.

El-Shahawy, M.I.; M.M.El Razaz and M.A. El-Biely (1997). Response of Giza 87 cotton variety to plant population density and nitrogen levels. J.Agric. Sci. Mansoura Univ., 22 (3): 689-695.

El-Shahawy, M.I.; S.M. El-Gahel and E.A. Makram (1994). Effect of planting dates, hill spacing and nitrogen levels on Giza 76 cotton cultivar. J. Agric. Res., Tanta Univ., 20 (4): 631-642.

Gomez, K.A.and A.A. Gomez (1983). Statistical procedures for Agricultural Research. 2nd Ed., Jhon Wiley and Sons, pub., pp. 139-153.

Heitholt, J.J.; W.T. Maredith and S.T. Rayburn (1998). Leaf area index response to four absolute and four modern cotton cultivars to two nitrogen levels. J. of Plant Nutrition, 21(11): 2319-2328.

Ismail, S.A.; M.S. Abo El - Nour and M.A. Nagib (2000). Influence of nitrogen fertilization and hill spacing on the productivity of Giza 80 cotton cultivar in middle Egypt - Fayoum. J.Agric., Res. And Dev., 14 (1): 179-189.

Makram, E.A.; H.A. El Aal; K.A. Ziadah and A.A. Darwish (1994). The interrelationship between dates and each of hill spacing and nitrogen fertilization doses for the Egyptian cotton cultivar, Giza 75. Annals of Agric., Sci., Fac. Agric., Ain Shams Univ., 39 (2): 609-622.

Makram, E.A.; K.A. Ziadh and W.M. El - Shazly (1995). The proper soil temperature for sowing cotton early. J. Agrc., Sci., Mansoura Univ. 20 (7): 3191-3199.

Mc Connell, J.S.; W.H. Bakar and R.J. Kirst (1998). Irrigation methods and nitrogen fertilization rates in cotton production. Arkansas Agric., Exper station, (188): 131-133.

Mc Farland, M.L., R.G. Lemon; F.M. Itons; P. Dugger and D. Richter (1999). Nitrogen management in ultra narrow row cotton proceedings Belt wide cotton conferences, Orlando, Floria, U.S.A, 3-7 January 1999 (2): 12791280.

Moore, S.H. (1999). Nitrogen effect on position of harvestable bolls in cotton. J. of plant nutrition 22 (6): 901-909.

Persley, J.P. Dugger and D. Richler (1999). Deltapine seed ultra narrow row cotton evaluation of DP 425 RR, DP 436, DP 5415, DP 4588 RR and DP 5111 IN Mississippi. Proceedings Beltwide cotton conferences, Orland, Florida, USA, 3-7 January 1999 (1): 477 -478.

Perumal, N.K. (1999). Effect of different nitrogen levels on morphphysiological characters and yield in rain fed. cotton. Indian Jour. Of plant physiology, 4 (1): 65-67.

Snedecor, G.W. and W. G. Cochran (1982). Statistical Methods. 7th Ed. lowa State Univ. Press Ames. lowa U.S.A. 507 PP.

Yasseen, A.I.H., A.Y. Negm and A.A. Hosny (1990). Effect of increasing population density and nitrogen on growth and yield of Giza 75 cotton variety . Annals of Agric. Sci., 53(2): 751 - 760.

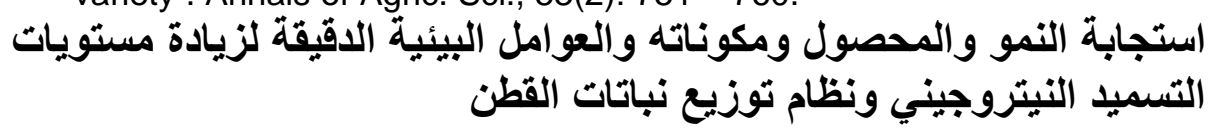




\section{سناء جمعه جبالي ـ مركز البحوث الزراعية ـ جيزة ـ مصر}

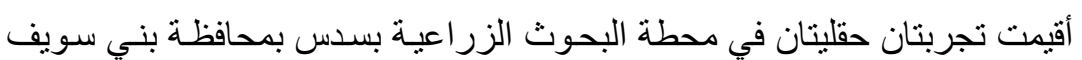

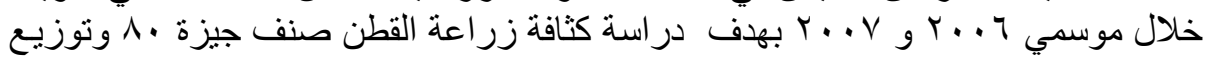

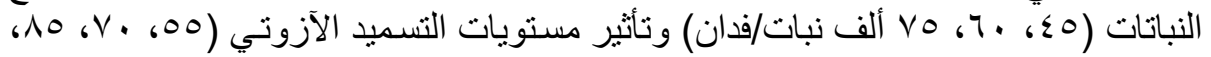

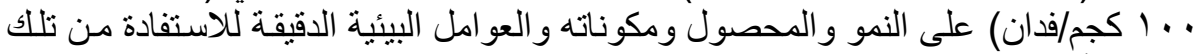

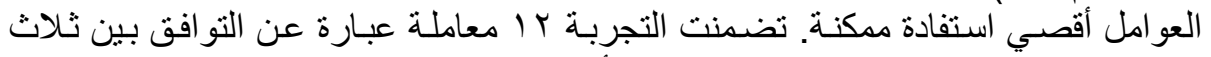

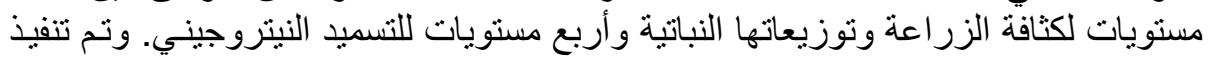

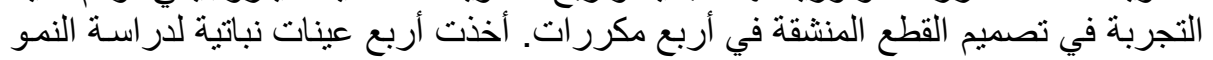

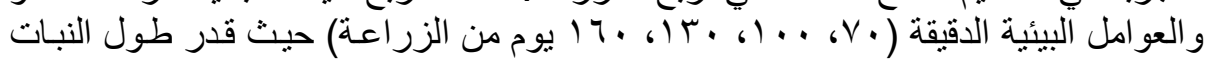

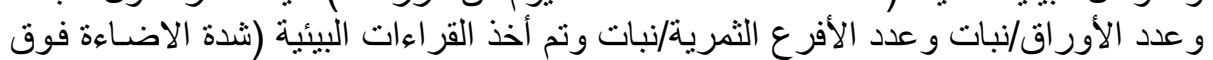

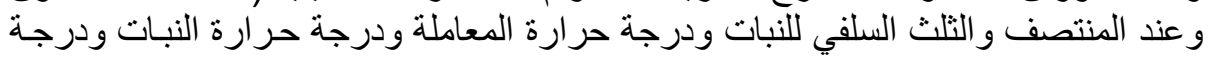

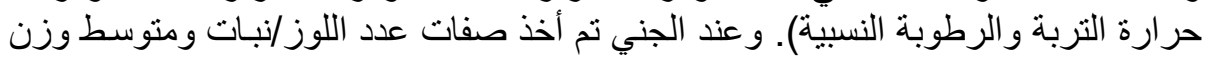

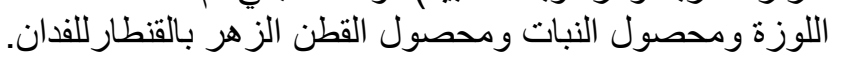

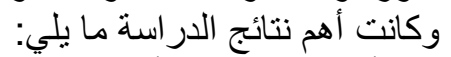

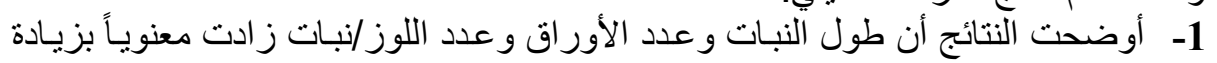

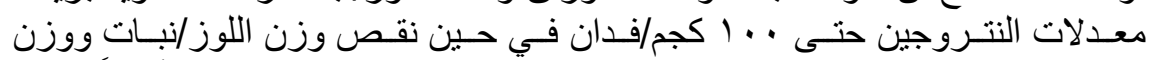

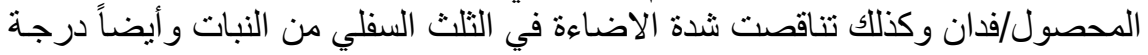

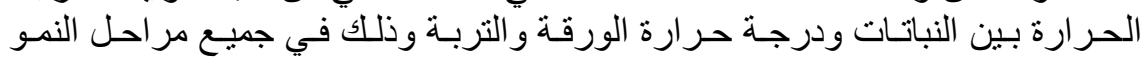

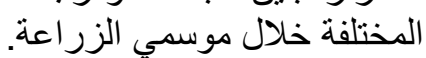

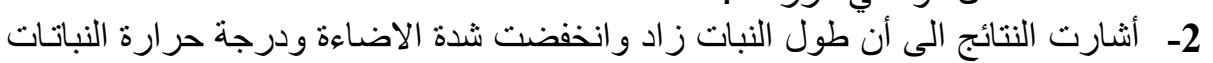

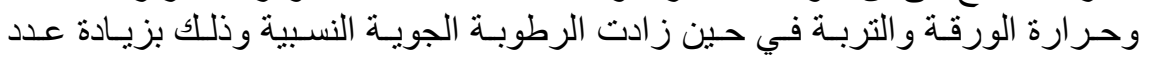

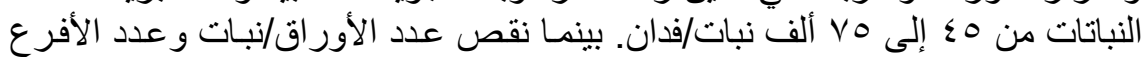

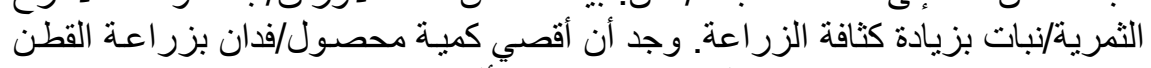

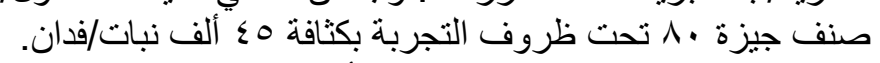

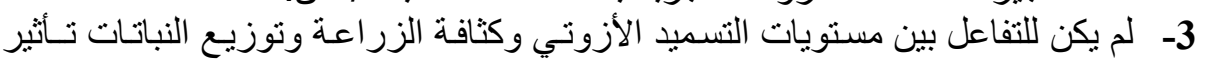

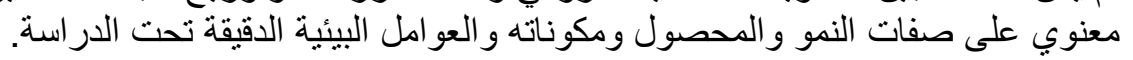


Gebaly, Sanaa G.

4743

4750 